\title{
Career Guidance for Youth Empowerment and Sustainable Development
}

\author{
Oyenike Alake Oyinloye \\ Department of Educational Foundations and Counselling, \\ Adeyemi College of Education, Ondo, Nigeria
}

\begin{abstract}
This study investigated how career guidance can be used to bring about youth empowerment and sustainable development. A sample of two hundred and three (203) secondary school adolescent students in Ondo Local government area of Ondo State participated in the study; they responded to a 18 item researcher developed Students' Career Information Questionnaire (SCIQ). The questionnaire has coefficient validity of 0.86 while two research questions and two hypotheses were generated for the study. Data were analysed using frequency count, t-test and ANOVA. The results of the study indicated that adolescents depend more on information from their peers in making career decision and that the adolescents' career choice is motivated by prestige and monetary gain. The study among other things indicated that adolescents should be guided on the right value system, choose career relevant to the societal needs and be encouraged to prepare for self employment rather than embarking on search for unavailable job. It was therefore recommended that guidance activities should be provided where none exist and that it be strengthened in schools to assist the adolescents to make meaningful career choice.
\end{abstract}

\section{Introduction}

The development of a nation relies to a large extent on the development and capacity of available human resources to meet the needs of the nation. The youth in our contemporary environment needs to be provided with adequate career information and guidance to assist him make realistic career choice if he would be relevant in the modern day society. Vocational guidance which is the process of helping an individual to choose, prepare, enter and progress in an occupation is a necessary step towards preparing and equipping the youth for productive work life. It is observed that there are different systems of vocational education from country to country to prepare an individual for the world of work. In the traditional Nigerian setting, there were limited occupational types available to the young ones and it was easy for the young adolescent to select the job he would enter into; more so when the profession which an individual could naturally imbibe is almost same as for all other members of the society, especially as majority enter into the agrarian occupation as the readily available one in the African setting. Oyinloye observes that, the child has available to him only limited opportunities to choose from, as he has the vocation either of the family or the predominant vocation in the environment where he belongs [15].

Monimah observes that for a country to develop her human capital adequately there is the need to strengthen and see to their development as a necessary step towards the actualisation of useful living for self, family and society at large ; human capital development being a bane of sustainable development [12]. The provision of career information is therefore a means to assist the young person to be well guided so that he could be exposed to a wide array of occupational information from which he would need to select appropriately.

The adolescent in today's word requires ample occupational information that will assist him to make a reasonable choice in a diversified work environment. Salami asserts that with the rapid increase in the number of available occupations, it becomes the more difficult for Nigerian parents to advise their children on matters of academic, career or vocational choice appropriately because they themselves are ill-equipped to make informed decision on vocational choice as their misconception about the nature of work denies the young ones of the opportunity to select occupations that will be relevant to the employment market [9].

The need for career guidance was captioned by the Federal Government in Nigeria in the National policy on education, NPE as necessary to assist the young ones in their choice of career. It also stress that career officers and counsellors should be appointed in schools to offer necessary guidance to students [6]. Ibok \& Ibanga see human capital development as a continuous process from childhood to old age and a must for any society to meet up with other nations [9] With this, vocational guidance was advocated and necessary machineries were put in place to train personnel that will provide the needed 
guidance in schools for the students to be prepared and assisted to enter into jobs.

However, with the increase in school enrolment, the number of school leavers outweighs the number of available job opportunities with its attendant evil of unemployment and other attendant problems. Adeyemo, while making reference to causes of unemployment in Nigeria, observes that:

(i) Nigerian students lack appropriate training on career prospects and job opportunities, hence ill-prepared persons keep joining the labour force;

(ii) the persistent high rate of unemployment opportunities exists in virtually all occupation because there is no meaningful placement for job seekers and that;

(iii) thousands of vacancies exist in many occupations that the unemployed people could not fill because they do not possess the necessary skills to take up the job [1].

In light of the above, the Nigerian children are faced by lack of information concerning educational opportunities, and information about careers that are likely to be relevant to the societal need and they are also confronted by the problem of contradictory occupational information derived through peer influence.

The modern society is thus becoming a more complex one as the young ones have a lot of occupations to choose from. The need to appraise the human capital needs in the country with the training of the adolescents in the Nigerian schools become evident so as to generate and develop matching guidance programme that will aid them in their choice of career. To guide the young ones on career, it may be required that the career exploratory ability of the youth be considered to trace his/her career inclination [7]. Career exploration according to Sherry should purposefully be directed at enhancing self-environmental consciousness and knowledge that individual would need in course of career development [10]. It is expected to be a life-long process of adaptation, growth and change while the ability to explore the environment and one's internal psychological resources is an important adaptive response to an era of rapid social economic changes. There is the need for provision of guidance to enable the adolescent match interest and personality with job demands in the country.

In the view of Durojaiye, vocational education should be provided to encourage individuals, especially the unemployed ones to become creative and stop searching for the jobs that are not there, rather they should start thinking of how to get themselves involved in doing one thing or the other on their own and therefore create employment for themselves, and if possible employ other people. [3] Vocational education to him will not only empower the youth with life sustenance/ employability skills to become productive and active participants in the task for socio-economic, political development and national unity. Youth empowerment has now been seen as a path that must be taken that will assist the youth to be self employed and not suffer the pain of unemployment. Olusakin asserts that counselling for sustainable livelihood will save the youth from abject poverty and it will in return enhance the economic sustainability of the of the country [13].

The major cry and clamour all over Africa including Nigeria is the creation of specific jobs to take millions of youth out of the shackle of poverty and underemployment, though at the obvious inability of the government to provide job for the large number of the unemployed. The most feasible solution out of the problem of unemployment therefore is to empower the youth. Youth empowerment in many nations is geared towards equipping youths with skills for self employment and nation building. The rate of unemployment and underemployment among Nigerian youths and graduates is on the rising, crime and poverty rate has equally increased. The federal government of Nigeria, International organizations and Non-governmental organizations have introduced some youth empowerment programmes to curtail the problem of unemployment in Nigeria [3]. Despite the efforts of the government and other bodies to help in curbing this situation, it all seems that the expected results of these programmes are not seen to be providing the desired outcome moreso when, the youths have not been fully able to enjoy the available opportunities as expected because of lack of information and guidance. Fareo observes that many adolescents are faced with inadequate vocational information, emotional inadequacies and social personal problems. To therefore overcome all forms of life inadequacies, guidance and counselling must then be provided [5] Amao-Kehinde, in same vein, predisposes that individuals have problems that he /she alone cannot solve, which could be educational, vocational or personal-social. And If such problems are not solved, they may tamper with the cognitive, rational and information dealing with reality. To this end career guidance is necessary for fruitful work life [2] and as a needful plan towards fruitful career life. Career guidance is therefore needed in schools and it should be such that will prepare the youth for self employment rather than seeking the non existing job. In addition, career guidance should focus on realistic needs and be such that will have relevance for the human capital needs and sustainable development of the nation.

\section{Research Questions}

i. How do adolescent students gather information about their career? 
ii. What are the factors that adolescents consider in choosing career?

\section{Hypotheses}

The following hypotheses will guide the study

i. There would be no significant difference in the career disposition of male and female adolescents

ii. There is no significant difference between students' class level and their career preference.

\section{Methodology}

The study was a descriptive research of the survey type, with a total of 203 adolescent students (60 males and 143 females) drawn from ten secondary schools in Ondo as participants in the study.

\section{Instrumentation}

The instrument used for the study was an 18-item questionnaire developed by the researcher, titled Students' Career Information Questionnaire (SCIQ). The questionnaire is an open ended one, giving the respondents the opportunity to provide answers as are applicable to each. Some items also enabled the respondents choose from a list of items that explains their views. The validity co-efficient of the instrument was found to be 0.86 while the reliability co-efficient was 0.78 . The instrument was thus found to be reliable for the study.

\section{Data Collection and Analysis}

The instrument was administered on the respondents by the researcher with the assistance of teachers in the schools used for the study. The data generated were analysed using frequency count, the t-test and analysis of variance (ANOVA) estimated at 0.05 level of significance.

\section{Results}

The results are presented in tables, 1-4.

Research Question one seeks to know how the adolescents gather information about their career choice

The various sources from which career information are gathered by the respondents are shown in Table 1.

Research question 2 factors that necessitated the choice on career chosen as presented in Table 2 .
Table 1. Sources of career information by adolescents

\begin{tabular}{|l|l|c|c|c|}
\hline S/N & $\begin{array}{l}\text { Sources of } \\
\text { information }\end{array}$ & Frequency & Percentage & Rank \\
\hline 1. & Peer & 61 & 30 & 1 \\
\hline 2. & Parents & 53 & 26.11 & 2 \\
\hline 3. & Neighbours & 32 & 15.9 & 3 \\
\hline 4. & Teachers & 21 & 10.24 & 4 \\
\hline 5. & $\begin{array}{l}\text { Guidance } \\
\text { Counsellor }\end{array}$ & 21 & 10.34 & 5 \\
\hline 6. & Others & 15 & 7.4 & 6 \\
\hline & Total & $\mathbf{2 0 3}$ & $\mathbf{1 0 0}$ & \\
\hline
\end{tabular}

Table 2. Factors that necessitated the choice of the career chosen by the respondents

\begin{tabular}{|l|l|c|c|c|}
\hline S/N & $\begin{array}{l}\text { Factors } \\
\text { affecting } \\
\text { choice of } \\
\text { career }\end{array}$ & Frequency & Percentage & Rank \\
\hline 1. & $\begin{array}{l}\text { Lucrative } \\
\text { nature }\end{array}$ & 64 & 31.53 & 1 \\
\hline 2. & Prestige & 52 & 25.62 & 2 \\
\hline 3. & Interest & 31 & 15.27 & 3 \\
\hline 4. & $\begin{array}{l}\text { Parents } \\
\text { wish }\end{array}$ & 22 & 10.84 & 4 \\
\hline 5. & $\begin{array}{l}\text { To secure } \\
\text { job easily }\end{array}$ & 21 & 10.34 & 5 \\
\hline 6. & Ability & 13 & 6.40 & 6 \\
\hline & Total & $\mathbf{2 0 3}$ & $\mathbf{1 0 0}$ & \\
\hline
\end{tabular}

Table 2 shows the various factors that influence the choice of career chosen by the respondents.

Hypothesis one stated that there would be no significant difference in the career pre-disposition of adolescent male and female.

Table 3. t-test result of students' gender and their career choice

\begin{tabular}{|l|l|l|l|l|l|l|}
\hline Variable & Mean & SD & Df & $\begin{array}{l}\text { t- } \\
\text { Value }\end{array}$ & $\begin{array}{l}\text { v- } \\
\text { value }\end{array}$ & $\begin{array}{l}\text { Decisi } \\
\text { on }\end{array}$ \\
\hline $\begin{array}{l}\text { Male } \\
60\end{array}$ & 1.372 & 0.151 & - & - & - & - \\
\hline $\begin{array}{l}\text { Female } \\
143\end{array}$ & 1.366 & 0.177 & 116 & -0.27 & 0.789 & NS \\
\hline
\end{tabular}

Significant at $\mathrm{P}<0.05$.

Table 3 shows the effect of gender on the career choice of the respondents. The analysis revealed that with the t-cal of 0.27 and critical value of 0.789 at 116 degree of difference based on sex and career choice, the hypothesis which states that there is no significant difference in the career, disposition of male and female adolescents is accepted at $\mathrm{P}<0.05$. This could be as a result of the fact that they live in same environments, and are faced by same environmental factors. 
Hypothesis two states that there is no significant difference between students' level and their choice of career

Table 4. Summary of ANOVA model on students class level and career preference

\begin{tabular}{|l|c|c|c|c|c|c|}
\hline $\begin{array}{l}\text { Sources } \\
\text { of } \\
\text { Variation }\end{array}$ & Df & SS & MSS & F & P & Decision \\
\hline Level & 2 & 0.1602 & 0.0801 & - & - & - \\
\hline Error & 115 & 1.9792 & 0.017 & 4.65 & 0.011 & 5 \\
\hline Total & 117 & 2.1394 & 0.973 & & & \\
\hline
\end{tabular}

Significant at $\mathrm{P}<0.05$.

Table 4 shows the ANOVA summary of students' class level and career preference, the analysis revealed that with the computed f-value of 4.65 and $P$ value of 0.011 and 177 degree of freedom, it indicates a significant difference among students class level in relation to career preference and choice. The hypothesis which states that there is no significant difference between the class level and career preference is therefore rejected at $\mathrm{P}<0.05$. This could be as a result of the fact that as the students' progress in educational level, their views, disposition in terms of work life become clearer and they therefore have better view of work and work value which ultimately determine their career choice.

\section{Discussion}

Career exploratory activities at the secondary school help to expand students understanding of the world of work by identifying career path ways and specific occupation within them, it is expected that when the adolescents have a wide range of opportunity to gather information from, they could relate the same to their personal interest, aptitude and environmental factors to be able to make a workable career choice. The result of the finding as revealed in table I show that the adolescents depend on their peer, parents, neighbours, teachers, guidance counsellors, and others for career information. Results of this study agrees with the findings of Togun which indicates that the influence of peer in the career choice of young ones is high as the services of guidance counsellors are less sought by students in the school setting [11]. From these results, it is clear that unless the activities of school counsellors are reviewed, their patronage may not be considered necessary, especially in the present age when the electronic media is taking over the roles of guidance counsellors in the area of career information.

It is however shocking to find out that the tastes and values of adolescent students are towards high financial yielding jobs. This simply shows that contemporary society is more interested in affluence, get rich quickly syndrome, with consciousness of wealth creation as major drive guiding the choice of career by the young ones. Interest, ability, contribution to societal good does not have any motivating effect on our youth; this is an ominous sign, to be watched. There is therefore need to emphasize contributory efforts from young ones to national life. The self - job creation option should be explored by the youth today to enable them work towards job creation rather than searching for the non existing job to be created by the government. [14]

The first hypothesis shows that there is no significant difference between the career disposition of male and female adolescents. The same environment makes and builds the male and female adolescents. The result of this study corroborates the findings of Eniayeju that women tend to improve the productivity level to meet their male counterparts; thereby bringing up the two in terms of making choice of career [4].

The second hypothesis also reveals that class/ level has effect on career preference of adolescents; this is so because, level of exposure to situations determines their focus and outlook. The career preference of adolescents change with their level of exposure, especially in the educational level. The tendency is therefore that as adolescents progress in their studies, they become more realistic in their outlook in terms of matching ability with career choice. The results of the study affirms the views of Amao- Kehinde that there is the need for counsellors to assist the in-school adolescents so that they could be exposed to meaningful career information; as well expository teaching will assist to shape the conception of the young about career expectations.

\section{Conclusion}

On the basis of the findings, it is clear that career guidance is needed for Nigerian adolescents to enable them have right perspective of careers that will assist the country inculcate the right culture and value system that will pay off in the generation of upcoming school children. The school is expected to make conscious effort to train and direct the focus of Nigerian adolescents to such career options that will help the country to meet her manpower development. Based on the finding of this study, the following recommendations were made:

i. Schools should adequately engage guidance counsellors in schools. They should provide career guidance to assist students make career choice in areas of manpower needs

ii. As a matter of urgency, there should be introduction of formal vocational education right from the basic education level.

iii. Empowerment of the youth is a must to enable them make their own contribution to 
national development, this can only be achieved through direct guidance that prepares the youth as creator of employment rather than being consumer of labour.

iv. Education curriculum and standards of education should be reviewed from time to time to reflect the needs and aspirations of the society.

v. Career orientation should be given to assist the young ones to have clear and worthy information about the world of work and what is required from individuals to enter into any job

vi. Parents should only guide and not impose career on their children as interest, and personality are factors in career success.

vii. Entrepreneurial skills should be developed in young ones to make them think along the path of entering into vocations relevant to the needs of the society, as they create and sell their own ability.

\section{References}

[1] Adeyemo, D.A. (1997). The didactic mode of career education and values clarification as strategies in fostering the vocational maturity of Nigeria Adolescent unpublished Ph.D thesis. University of Ibadan, Ibadan.

[2] Amao - Kehinde, A. O. (2015). Guidance and counselling issues in Educational Reforms for Quality Assurance in Nigeria. Lead paper presented at the $5^{\text {th }}$ Annual Conference of School of Education, Adeyemi College of Education, Ondo. April 15.

[3] Durojaiye, A. M. ( 2015). Functional Vocational Education for Youth Empowerment. Paper presented at the $5^{\text {th }}$ annual School of Education conference, Adeyemi College of Education, Ondo. !4- $15^{\text {th }}$ April.

[4] Eniayeju, O. (1995): Womanhood and family life in Nigeria in choice of career and expected sex-role in Nigeria by Ike. Quarterly Journal of the Federal Ministry of Education.

[5] Fareo, D.O.(2015). Challenges of Guidance and Counselling in Nigerian Educational Reforms. Paper presented at the $5^{\text {th }}$ Conference of School of Education, Adeyemi College of Education, Ondo. 15-18 ${ }^{\text {th }}$ April.

[6] Federal Republic of Nigeria (2004). National Policy on Education (revised) Lagos, NERDC.

[7] Holland, J. L.( 1959). A theory of Vocational Choice. Journal of Counselling Psychology, 6 (1) 35 -45.

[8] Ibok, E. F. \& Ibanga, S. E. (2014).The impact of human capital development and economic development on the socio - economic empowerment of Akwa Ibom State, Nigeria. Global Journal of Human Resources Management. 2 (3) September 37-44
[9] Salami, S. O. (1999). Demographic, locus of control and self-concept as determinants of career maturity among Nigerian adolescents. Nigerian Journal of Applied Psychology. 5 (1) 150-161

[10] Sherry, P. (2002): Comparing the effectiveness of two self-administered career Exploration system. The Career Development Quarterly 45 (2) 170-172.

[11] Togun, O.R. (1999): Career exploration behaviour of primary school pupils. Unpublished Research Project submitted to Adeyemi College of Education, Ondo.

[12] Monimah, H.D.( 2010). The centrality of human capital development to the attainment of Nigeria's Vision 20:2020 development programme. Journal of Sustainable Development in Africa. 12 (5). 139 -155.

[13] Olusakin,A.P. (2010). Counselling for Sustainable livelihoods with target Clients: the Nigerian Adolescents and Youths. Lead paper presented at the 2010 conference of the Counselling Association of Nigeria (CASSON).

[14] Osanyintuyi, S.O. (2005): Appraisal of Career Guidance Services in some selected Secondary schools in Ondo. Research Project submitted to Adeyemi College of Education, Ondo.

[15] Oyinloye, O. A. (2015): Career guidance for human capital development and sustainable development. Paper presented at the 2015 London Conference on Education held at Marriott Windsor Hotels, London, 9- $11^{\text {th }}$ November. 